\title{
Baudelaire'de Söylenin Söyleme Dönüşümü: Dionysos ${ }^{1}$
}

\section{Yavuz KIZILÇIM ${ }^{2}$}

\begin{abstract}
Özet
Bu çalışmada Baudelaire'in (l'Ame du Vin) Şarabın Ruhu şiirinin bilişsel söylemi şarap tanrısı Dionysos söyleni temel alınarak değerlendirilecektir. Ozanın, söylen tanrısını konuşturarak, onun tüm birikimini insana yatıran öyküsünü şiirine konu edinerek, insanın yeryüzü serüvenini şarabın üretim serüveni üzerinden etkinleştirdiğine tanık oluyoruz. Ozan kendine özgü bir simgeleştirme ve tasarım anlayışıyla oluşturduğu şiirinde şarap söyleni üzerinden insana değgin tasarılarını şiirleştirme olanağı bulur. Şiirin öznesi şarap üzerinden insana yatırım yapan Dionysos'un sözleriyle ilerde bir kazanç sağlamak yönündeki (iyi) niyetini sezdirerek dizeleri gelecek zaman kipinde sözceliyor. Ozanın, söyleni farklı bir algılama düzlemine aktarmada, söylen bu yeni boyuta taşınırken derin ve yüzeysel yapıyı birbirine bağlayan dönüşüm işlemlerinde, söylen tanrısının yaratıcı edimlerine yerinde karşılıklar yükleyerek sözcelemesi, öncelikle bu, Baudelaire'e özel dilbilgisini ele almayı zorunlu kılıyor. Bu bağlamda şiir, söylenin insan bilişselliğindeki karşllıklarıyla örtüşmesi ve/veya örtüşmemesi dikkate alınarak irdelenecektir. İnsanı günlük telaşlarının, basit kaygılarının odağında sergileme, tanık olduğu durum ya da olayları söylene özgü sözvarlığıyla dile getirerek şiirleştirme anlayışı Baudelaire şiirinin bilişsel söylemini oluşturuyor. Bir ozan olarak o, duyarsız kitleyi daha çok insani değerler açısından değerlendirir ve tümüyle olumlu bir tasarım ilkesi üzerinde yoğunlaşarak şiirine taşıdığı bu bilişsel yapıyı, okurun bu konudaki önceki bilgilerini etkinleştirerek şarap göstereniyle bağdaşık eğretilemelerle şiirleştirir. Şiirde yatırımı önceleyen bir tasarım dizgesinden yararlanır ve bu şekilde söylen aracılığıyla asıl gerçeği buldurma ve eldeki verilerden olmayana ergi yöntemini yeğler, özetle Dionysos söyleni Baudelaire şiirinin söylemini oluşturuyor.
\end{abstract}

Anahtar Sözcükler: Dionysos söyleni, şiirin bilişsel söylemi, şarabın tini, gelecek tasarımı, yatırım

\section{Transformation Of Myth Into Poetic Discourse In Baudelaire: Dionysos}

\begin{abstract}
In this study, the cognitive discourse of the poem Soul of the Wine (l'Ame du Vin) of Baudelaire will be examined in the framework of Dionysos's myth. We see that the poet tells the adventure of the humanity through the adventure of wine making by making the mythological god speak and using his story in the poem. The poet, with a sense of symbolization peculiar to him, finds the chance to include his ideas about the humans in his poems through the myth of wine. The subject of the poem utters the lines in the future tense with using the words of Dionysos and implicating his goodwill in terms of deriving benefits. Examining Baudelaire's special grammar becomes a requirement in transferring the myth into a different perception level and in these transferences which connect the deep and surface structures. In this context, the poem will be examined by taking into consideration whether the myth corresponds to its counterpart in the human cognition or not. The cognitive discourse of Baudelaire's poetry consists of depicting the human with his simple, everyday concerns or telling the situations and the events that he witnesses in
\end{abstract}

$1 \quad \mathrm{Bu}$ makale XI. Ulusal Frankofoni Kongresi kapsamında 12 Mayı 2015 tarihinde Yıldız Teknik Üniversitesi’nde sunulan metnin genişletilmiş halidir.

2 Doç. Dr. Atatürk Üniversitesi Eğitim Fakültesi Fransız Dili ve Edebiyatı Eğitimi, ykzlcim@yahoo.fr 
the vocabulary of the myth. As a poet, he evaluates the insensitive masses in terms of the humanitarian values, he concentrates on total positive design principles and by activating the readers' prior knowledge, he writes his poems with metaphors coherent with the wine signifier. He prefers the method in which he makes the readers find the truth through myths by navigating them from the data available to unavailable. In conclusion, it can be said that the myth of Dionysos forms the poetic discourse of Baudelaire.

Keywords: Dionysos's myth, cognitive discourse of poetry, soul of wine, future representation, investment

\section{O. Giriş}

Baudelaire'in (L'Ame du Vin) Şarabın Ruhu şiiri geniş ölçüde Dionysos söyleni bağlamında kurulmuş bir şiirdir. Bizim örneklem olarak bu şiiri seçme nedenimiz şiirin bilişsel söyleminin çözümüne olanak sağlayacak ölçütlere uygunluğudur. Burada, ozanın kendine özgü bir söylemle oluşturduğu şiirini Dionysos söyleniyle etkinleştirme yoluna gittiğini gözlemliyoruz: Baudelaire bu şiirinde sağır ve dilsiz kitleye yönelik eleştirisini onun tanrıyla ilişkisini tartışmaya açan bir yaklaşımla sürdürüyor. Şiir/ söylen ikilisi açısından duruma yaklaştı̆̆ımız zaman bu şiir bağlamında ortaya çıan en ayırt edici nitelik Dionysos'un eylemleriyle şiirin her yerinde bulunmasına karşın isminin örtük bir içerik olarak saklı tutulmasıdır. Bu örtülü söylemin ozanın bilinçli bir seçimi olduğunu düşünüyoruz; çünkü ozan, Dionysos'un tıpkı gerçek bir tanrı gibi görünmeden edimleri yoluyla tanınmasını, algılanmasını ve bulunmasını bekler. Gözlemin ve tanıklığın bu tür görülmeyeni buldurmaya dayalı sözcelerle geliştirildiği Şarabın Ruhu şïrinde, insan yeryüzü serüveninde birbirine karşıt nitelikleriyle tanımlanarak aynı zamanda hem (cher) sevgili, sevimli, aziz, hem de (déshérité) yeteneksiz, nasipsiz ve kalıttan yoksun olarak gösteriliyor.

\section{L'Ame du Vin/ Şarabın Ruhu}

1Un soir, l'âme du vin chantait dans les bouteilles (Șișelerde bir akşam şakır şarabın ruhu)

2Homme, vers toi je pousse, ô cher déshérité, (Derdi: Sana, her şeyden yoksun, sevgili insan)

3Sous ma prison de verre et mes cires vermeilles, (Bir şarkı yolluyorum kardeşlik, ışıı dolu)

4Un chant plein de lumière et de fraternité! (Pembe balmumu ve cam zindanımın altından!)

5Je sais combien il faut, sur la colline en flamme, (Bilirim, bir tutuşmuş tepe üstünde niçin)

6De peine, de sueur et de soleil cuisant (Onca didinme, ter ve kavuran güneş gerek)

7Pour engendrer ma vie et pour me donner l'âme; (Var olmam ve kendime bir ruh edinmem için)

8Mais je ne serai point ingrat ni malfaisant, (Ama nankör, kötücül olmayacağım gerçek)

9Car j'éprouve une joie immense quand je tombe,(Çünkü sonsuz bir sevinç duyuyorum düşerken)

10Dans le gosier d’un homme usé par ses travaux, (Uğraşıp yorulmuş bir insanın gırtlağına)

11Et sa chaude poitrine est une douce tombe (Onun sıcacık göğsü tatlı mezar ki, en)

12Où je me plais bien mieux que dans mes froids caveaux. (Soğuk mahzenlerimden daha hoş gelir bana) 
13Entends-tu retentir les refrains des dimanches (Duyuyor musun, pazar ezgileri çınlamada)

14Et l'espoir qui gazouille en mon sein palpitant? (Ve çırpınan göğsümde cıvıldayan umut bu?)

15Les coudes sur la table et retroussant tes manches, (Kolların sivalı ve dirseklerin masada)

16Tu me glorifieras et tu seras content; (Kutlayacaksın beni için gönençle dolu)

17J'allumerai les yeux de ta femme ravie; (Ateş yakıp gözünde karının, sana hayran)

18A ton fils je rendrai sa force et ses couleurs (Kavuşturup oğlunu gücüne, renklerine)

19Et serai pour ce frêle athlète de la vie (Güreşçilerin kaslarını sağlamlaştıran)

20L'huile qui raffermit les muscles des lutteurs. (Yağ olacağım yaşamın o körpe erine)

21En toi je tomberai, végétale ambroisie, (Düşeceğim içine, tanrısal balözü ben)

22Grain précieux jeté par l'éternel Semeur, (Değerli tohum, sonsuz Ekici'nin serptiği)

23Pour que de notre amour naisse la poésie (Şiir doğsun diye ikimizin sevgisinden)

24Qui jaillira vers Dieu comme une rare fleur! (Fışkırarak Tanrı'ya eşsiz bir çiçek gibi!) (FM, 2011:162/ KÇ, 2006:195)

\section{Dionysos söyleni}

Bir akşam "Dionysos" (şarkı söyler gibi) bir ses tonuyla konuşur ve şöyle der: her şeyden yoksun, sevgili insan, ben Dionysos olarak sana kardeşlik ve ışık dolu bir şarkı gönderiyorum: bu şarkıyı özellikle senin için yazdım. Bu sarkı tüm güzellikleriyle insanı, mevsimi, üzüm asmalarının verimliliğini, güvenlik ve esenliği dile getirir. Bir ruh böyle Dionysos'un onuruna erişerek onunla doğrudan konuşma firsatı bulursa, elbette ikisinin sevgi sözlerinden şiir doğar ve bu şiir benzersiz bir çiçek gibi Tanrıya yükselirken, beraberinde onları da yükseltir. Latince adı Bacchus olan Dionysos üzerine bilgileri kısaca özetleyelim, şarap, kutsal üzüm suyu insandaki coşkun nitelikleri etkinleştirmeye aracılık eder: Dionysos, tanrılar ülkesine dışarıdan gelme bir tanrıdır ve yeryüzündeki edimleri büyük ölçüde tepki ve direnç üzerine kuruludur. Annesi Semele'nin ona yedi aylık hamileyken ölmesiyle, Zeus onu yaşatmak için yanına alır ve baldırına yerleştirir böylece, ikinci bir doğumla Dionysos'u meydana çıkarır: Athena, Zeus'un kafasından Dionysos ise baldırından doğar. Zeus'un baldırından doğması onun özellikle kas ve kaba yaptırım gücünü imgeler. Dionysos üzüm suyunu bulur ve onu kullanarak insana șarap üretmesini öğretir (Dictionnaire Des Symboles, 1982: 1012-1016) / (Erhat, 1989:102-103-104). Şiirde Dionysos tanrısal bir güç, daha çok insanın bedeninde ve tinindeki görülmeyen, yalnızca duyularla sezilebilen etkin bir güç olarak tasarlanıyor: Şarabın Ruhu'nda Dionysos söyleni güncellenerek bütün bir insanlık durumunu simgelemek, somutlaștırmak üzere özellikle seçilmiștir. Şiirin başlı̆̆ında (l'Ame du Vin) yer alan şarabın bir ruhu olabileceği varsayımı toplumsal bellekte, şarapla insan arasında kurulan bağdaşık ilişkilerle, sayısız anlama gönderimde bulunuyor.

Şiirde sözcüksel art gönderim yoluyla (değerli tohum) diye nitelenen bu tin çağlar boyu yinelenen söylenlerle sonraki kuşaklara aktarılmış Dionysos'un tinidir ve bu tin etkinliğini kanıtlamak adına sık sık insanları zevk'ten öldürür: Öyleyse, bilinçdıșı, düșüncelerin çatışmalı bir oyununu gösterir ve aynı şekilde bizlerin içsel durumuna kendi gerçekliğini kazandıran acı ve zevk arasındaki bu karșıtlıktır. Eğer bireysel doğamız bir kararlılık 
durumunu gösteriyorsa, bu, acının sürekli olarak zevk'e dönüștürülmesindendir. Aynı şekilde, Kant fizikte kararlı itici güçlere, özdeğin anlaşılması yolunda, çekici güçlerden daha fazla önem verir ve benzer şekilde, onun anlayışına göre acı, bizim doğamıza gerçekliği kazandıracak biçimin tersine arzuyla değiştirilen yaşamsal gücü eyleme geçirendir. Çatışma dışında, kendi haline terk edilmiş bir tatmin durumu zevkten ölmeyle sonuçlanacaktır (Tod vor Freude / Mort de joie) (David Ménard, 2005: 195-198). Tinsel açıdan şiire konu edilen böyle bir zevk algısını şarabın bastırılmış duyguları açığa çıkarma gücüyle açıklamak olasıdır: sözgelimi, Dionysos şaraptan çıldırmış kadınlar (Bakkhalar) Mainadlar'ı dağlara, ormanlara salar, bu kadınlar kanlı avlara çıkarlar ve yakaladıkları yabani yaratıkların kanını içerler. Şaraptan söz edildiğinde şiirin konusu kimi kez insana umut ve coşku veren, kimi kez zevkten öldüren Dionysos ayinleriyle bağıntılandırılır. Söylenbilimde Dionysos'a yüklenen zevk sahibi (oluş) niteliği ondaki acının sürekli olarak zevkle birlikte düşünülmesinden ve bu düşüncenin zevkten çıldırma/ ölme gibi karşılıkları bulunmasındandır.

Akşam vakti çevresine ışılar yayarak ortamı görkemiyle ve büyüsüyle aydınlatan Dionysos şenliklerinde şarap testilerinden süzülen üzüm salkımının özü (baştan başa ışık ve kardeşlik) esinleyen görüntüsüyle cam hücresinde ve pembe mumların ışıltısında gösterilmiştir. Şiirdeki öznenin şarap algısı, okur henüz şarabın tini olacağı düşüncesine alışmamışken söylenin tüm bilişsel içeriği bir akşam zamanı şişede ezgiye dönüşürken gösterilir, yani şarap sürahiden kadehe dökülürken duyulan ritimli ses ona bir şarkı gibi gelir: Doğan'a göre bu ritmik ses Arapçada (kulkul) adıyla anılır ve "söyle, söyle!" anlamına gelir (Doğan, 2008:66). "Un soir, l'âme du vin chantait dans les bouteilles: șișede şakıyordu, akşam, șarabın ruhu" dizesinde öznenin şarap şişesine gönderimde bulunması, öncelikle şarap şişesinin çağlar boyu eğretilemeli bir tasarım değeri taşımasındandır: O olağanüstü hayal görüntülerinin, peri kızı gibi her kılığa giren anlam güzellerinin ortaya çıktığı sihirli bir şişedir (Doğan, 2008:95), bir kez daha (şarabın tini/ șișede şakıyordu) sözcesinden yola çıkarak, belleğimizdeki önceki bilgileri gözden geçirdiğimizde Alaeddin'in Büyülü Lambası gibi fantastik masallarda cin, peri vb. gibi insanüstü yaratıkların lamba/şişe içinde saklanması ve gerçeği açıklama zamanı geldiğinde büyü işlevini yerine getirmek için dışarı çıkmalarını anımsıyoruz. Yani aslında, ozanın şiirde yeni bir algılama düzlemine aktardığı bu bilgiler okura pek yadırgatıcı gelmez, çünkü söylen yeni bir boyuta taşınırken insanların belleğinde bu şekilde söylenle ya da masallarla etki alanı yaratmış şarap üzerine kurulu bilişsel bir anlam alanı zaten bulunmaktadır.

Söylende ayrıntılandırılan bilgilere ek olarak, Dionysos kadehinin yatıștırıcı etkisi oldukça ünlüdür; bu kadehten içenlerin cesaretinin çoğalacağına, korkularından kurtulacağına ve tanrılaşacağına inanılır. Tüm bu dizelerdeki ve söylendeki bilgileri karşılaştırarak bağıntı çözümlemesi yaptığımızda yani, şarabın kırmızısı, ateşin kırmızısı, ışık kümeleri, akşamın kızıl rengi, alevli tepe, yakıcı güneş gibi söz öbeklerinin şiirde yaratılmak istenen atmosferi renkleriyle zenginleştirmek ve onlara çoklu nitelikler kazandırmak üzere özellikle seçildiklerini görüyoruz ve yoğun kırmızı renk seçimi Dionysos şöleninin başlaması için gerekli olan ateşe gönderimde bulunuyor. Söylene göre, Dionysos yakıcı ateşten yaratılmış ve serinletici suyla büyütülmüştür. Şiirde Dionysos'un yerine konuşan gizli bir özne bulunuyor: böyle olduğunu "biliyorum üstünde bu alevli tepenin/ de peine, de sueur et de soleil cuisant "onca didinme, ter ve kavuran güneş gerek/ hayatımı yaratmak, ona ruh katmak için" dizelerinde (biliyorum) diye başlayan dizeler kanitlar; bunlar bellek okuma yoluyla "ben biliyorum" öyleyse bu bilgiyi başkaları da (bile)bilir anlamına gelir. Pour engendrer ma vie et pour me donner l'âme; (var olmam ve kendime bir ruh edinmem için) dizesinde "engendrer" eyleminin sözlük anlamı (erkekler için) döllemek, birinin dünyaya gelmesine olanak sağlamaktır. Burada "emek" düşüncesi art gönderimsel olarak örtük durumdadır: Bu dizede eylemlerin değişimi, bilgilendirici yapısından dolayı şiiri sözceleyen öznenin "biliyorum" ile başlayan yinelemeleri sözdizimsel olarak "hayatı yaratmak" eyleminin öznesini tanımlamada (yaşamı) "ona" diye yineleyerek "ona ruh katmak" eylemini imlemesi ve yaşam sözcügünün 
özel olarak süreğen bir anlamı içermesi şiirdeki en küçük bileşenin (bile) özne tarafından Dionysos'un şiirdeki varlığını kanıtlamak üzere kullanıldığını gösteriyor. Biliyorum, diye başlayan bu sözce bir bilgiyi paylaşmasıyla bilişsel bir sözcedir ve ozan şiirdeki Dionysos tasarımını, örtük bilgiye eşitleme aşamasında yaşam üzerine kendi bilgilerini ortak bir yaşam deneyimine aktardığı için bilinçle söylendiğini düşünüyoruz. Özne, şaraba diriltici bir güç yüklerken, bu gücün niteliği (yakıcı güneş, eziyet ve ter) söz öbeklerini içeren emek düşüncesiyle belirlenir, böylece bilişsel uzamını genişleterek şiiri daha geniş bir coğrafyaya yayar. Bunu yaparken insan emeğinin günlük yaşamdaki karşılığının şiirde Dionysos adına konuşan özne tarafından eğretileme yoluyla güncelleştirilerek kişisel söylene dönüştürüldüğünü gözlemliyoruz. Şarabın şişede "şakıma" yani dile gelme ve konuşma eğretilemesi simgesel olarak yüzyıllardır yinelenen bir (ön) bilgiyle onun imbiklerde sabırla süzülerek damıtılması ve bambaşka bir niteliğe bürünerek insanları günlük sorunlarından kurtaran ve alıp götüren yönlerinin karșllı̆ı olarak sözcelenmistir: Öznenin șarapla insan türü arasında bağlantı kurma çabası şiirin bilişsel niteliklerinin tümünün bir süreç içerisinde anlaşılmasını sağlar. Şarap olarak şişelenmiş sıvının kabına sığmaması, taşkın etkisi ve bunları aşan özelliklerinin karşıllğı olarak dile getirilmiştir.

Şiiri sözceleyen özne ve onun yaşam deneyimleri üzümün yetiştirilmesinde harcanan emeği açık bir benzetimle insanın yetiştirilmesiyle denk tutması şiire gerekli bilişsel altyapıyı hazırlıyor. Şarabın tiniyle bağlantılı olarak tasarımlanan insan emeği şiirde insanın yeryüzündeki edimlerinin çoğaltıcı bir anlam değerine sahip olmasını imgeliyor: $\mathrm{Bu}$ bağlamda şiirin öznesi tasarım ve gösterim nesnesi olan şarabı kimi bağdaştırmalarla insan tinine yakınlaştırıyor ve zamanlar üstü bir noktaya yerleştiriyor.

\section{Yatırım düşüncesi}

Dionysos, insana seslenerek (kutlayacaksın beni için gönençle dolu) derken, aslında (ben) seni mutlu edeceğim, bedenini ve tinini besleyeceğim, eksik yanlarını gidereceğim, sen de (benim) bu edimlerimin karşılığ yücelteceksin, diye karşılık verdiğinde, bu söylemin karşılığını yatırım başlığı altında ele alıyoruz. Yani, Baudelaire belli bir hedefe yönelen ve ağırlıklı olarak gelecekte bir gelir veya sürekli kazanç sağlamak için önceden ortam hazırlamanın yolu olarak (yatırım) düşüncesini öne çıkarıyor: Dionysos şarap üzerinden insana yatırım yapmıştır.

Şiirin bütününde şişelerden (bouteilles) yansıyan (soir) akşamın renkleri artgönderim yoluyla (şarap) ve şarap kırmızısı üzerine kurulu renk söylemleriyle pek çok kez yineleniyor: (bir akşam şarabın ruhu șișelerde şakır) (kardeşlik, șsı dolu bir şarkı) yine benzer renklere bağlı olarak sözcelenen alevli pembe ve balmumu renkleri, ardından bütün gün yorucu işlerde çalışmanın karşılığı olarak ter ve kavurucu güneş, yine ateş ve sıcaklığa gönderen sicak göğüs/ tatlı mezar iminin karşılığı emek düşüncesinin yerini alıyor. J'allumerai les yeux de ta femme ravie (ateş yakıp gözünde karının, sana hayran), ayraç içinde yazdığımız dizelerde "aşk" kavramı somut olarak yer almaz, fakat adı belirtilmeden, aşk ateşini yakmak deyim anlamında, yani gizli bir içerik olarak varlığı duyuruluyor. O zaman şişeden yükselen şarabın, şarap tanrısı Dionysos'un sesi, Baudelaire'in seslendirmesiyle duyulur ve bu ses insana seslenir ve ey insanoğlu, canlılık esinleyen bu şarkı senin için yazılmıștır, (bunun için aşkımızdan şiir doğsun yine/ benzersiz bir çiçek gibi Tanrı'ya yükselen!) aşkımız şiire kaynaklık etsin, bu şiir çiçek gibi gökyüzüne yükselsin, der. Bu nedenle aşk'tan şiir doğmasının yolu insanın şarabın esiniyle kendi tininin doğurgan ve yaratıcı niteliklerinden beslenmesine bağlanmıştır. Bunlara ek olarak, şiirde kulak ver (coşkulu kalbimde cıvıldayan) umudu dinle sözcesindeki "kulak ver" deyimi işitme duyusuyla bağlantılı olan cıvıldamak; kuş gibi neşeyle (cıvıl cıvil) ötmek yinelemeli ses öbeğiyle birlikte kullanılmıştır. Nesne-özne arasında kurulduğu varsayılan bu ayrıcalıklı ilişkide öznenin tanıklıkları, duyularıyla 
algıladığı, ayırdına vardığı bağlantılar şiirsel bağlamın belirleyicileridirler. Şarabın Ruhu'nda bu ilişki şarapla insan arasındaki bağıntıyı bir yatırım düşüncesi aracılığıyla etkinleştiriyor.

Burada Dionysos esiniyle dile getirilen ve eğretilemeli olarak şarabın esiniyle sözcelenen dizelerde, "de peine, de sueur et de soleil cuisant (nice yakıcı günes, eziyet ve ter lazım)/ pour engendrer ma vie et pour me donner l'âme; (hayatımı yaratmak, ona ruh katmak için) üzüm asmasının kuru toprakta gelişip serpilmesi insanın yeryüzündeki yaşam serüveniyle bağdaşı olarak sözcelenmiştir: şiirin söylemi şarabın tinini kuru bir üzüm dalının varlığıyla açı $(\mathrm{k} / \mathrm{m})$ layan ve ona olumsal nitelik kazandıran tüm bileşenlerin etkileşimiyle güncelleştirilen bilişsel bir süreci imliyor. İnsanın da, üzüm asmasının da yetiștirilmesi üretken bir yatırım düşüncesine bağlı olarak büyük bir özveri ve emek gerektirir. Ancak herkesin işine yarayacak bu kadar emek elbette karşılıksız kalmaz ve insanoğlu üzüme yatırımının somut karşılığını üzümden şarap, kadından (evlat) alarak yaşam boyu almayı sürdürür.

"Mais je ne serai point ingrat ni malfaisant/ ne var ki, kötücül ve nankör olmayacağım", bu birimde konuşan özne kötücül ya da nankör olmayacağım derken, bu bağlamda insanların çoğunun "kötücül ve nankör" olduklarını gündeme getiriyor. Yani insanlar genellikle mutlu olmanın yolunu bilmezler ve kendilerine sürekli üzüntü duyacakları bir sorun ararlar ancak şarabın tinini göstergeleyen (ben) Dionysos başkaları gibi kötücül ve nankör olmayacağım, der: (ingrat) nitelemesi sözlükte verimsiz, kötücül, sevimsiz, iyilik bilmez anlamlarına gelir; bu olumsuz niteleme, yaşam karşısında yeterince direnç ve tepki göstermeyen bütün insanları nitelemek üzere özellikle seçilmiştir, diye düşünüyoruz. Özne yaşamda "kötücül ve nankör" olmama önerisini "une joie immense" (sınırsız bir sevinç) duymak önermesiyle birleştiriyor ve bu önermeyi şiirin doğurgan nesnesi şarapla bağdaştırıyor. (Zira is yorgunu birinin kursağına/ dans le gosier d'un homme usé par ses travaux/ düştügüm vakit sonsuz bir sevinç duyarım ben) dizesindeki "le gosier d'un homme" belirlemesi "şarabın" insanın konuşmasını, başka insanlarla iletişime girmesini sağlayan boğaz, yutak, gırtlağından geçtiği andan başlayarak, ona gündelik yorgunluğunu unutturacağı, sorunlarını gidereceği anlamlarıyla örtüşüyor. Bu bağlamda, insanın yeryüzündeki eylemlerinin somut karşıllı̆ı gündelik etkinliklerinin sonucunda acıkmasıyla, boğazının kurumasıyla, (iş) yorgunu olmasıyla belirginleştiriliyor. Gerçekte, insanın yeryüzündeki tüm eylemleri burada, bu yatırım düşüncesinde düğümlenir, çünkü insanoğlu karşılık beklemeden, deyim yerindeyse kılını bile kıpırdatmaz: insanın emek harcayarak kimi nesneleri elde etme ve onları bir süreklilik ilkesine bağlı olarak yaşatma edimleri diğerlerinin önüne geçer. İnsan yeryüzü serüveninde yüce gönüllü fakat eylemlerinde yeteneksiz gösterilmiştir; yani, insan yaşamda kimi hedeflerine ulaşsa bile, bu ulaşım onun sonu gelmez arzularını gidermeye yetmez, çünkü insan yeryüzü serüveninde tatminsizdir ve eyleme geçtiği her defasında elindekinden daha fazlasını arzular: en uzun iyelik bile onu ikna etmeye yetmez; gözünü hırs bürümüştür ve onun boğazının kurumasına yol açan, onu susatan zevk bu şiire konu edilen diyonizyak zevktir: insan (beğenen ben) olarak yeryüzü zevklerini ve her gün yeni bir dirençle yaşama tutunma gücü ve kararlılığını bu yatırımla sağlanan süreklilik ilkesinden ödünç almıştır.

(Onun sıcacık göğsü tatlı mezardır bana/ burası çok daha hoş soğuk mahzenlerimden) dizesindeki "tatlı mezar/ soğuk mahzen" bağdaştırmaları şarabın belli bir kıvama ulaşması için yıllarca bekletildiği yer bakımından tümüyle sezdirimlere dayalı bir karşılaştırmayı imliyor. Şarap soğuk mahzende canlıdır, fakat biri onu tükettikten sonra, birinin midesine düştüğünde, biri onu içtiğinde canlılığını yitirir ve onun midesi, bir mezar yerine dönüşür ancak kendi ölümü pahasına (uğraşıp yorulmuş bir insanın girtlağına/ düştüğüm vakit sonsuz bir sevinc duyarım ben) diyerek şarabın doğurgan diliyle, çalışmaktan yorgun düșen bir işçinin sıcacık göğsü tatlı bir (mezar) yeri olarak yansıtılır. Şarabın dinlenmeye bırakıldığı büyük tahta fiçı tatlı bir (mezar) yeriyle bağdaştırılıyor. Bu bağlamda, ozanın (soğuk mezar) söz öbeğini tatlı mezar nitelemesiyle yumuşatarak ona esenlikli duygu değeriyle olumlu bir 
anlam yüklediğine tanık oluyoruz. Burada aynı zamanda Dionysos'un hiç görmediği annesini yeryüzüne geri döndürmek için yeraltına inişine gönderme yapılmaktadır. Dionysos'un annesini bulması (onun sıcacık göğsü tatlı mezardır bana) dizesiyle kendi yaşamı pahasına Ölüm'e, Thanatos'a meydan okumayı göze alması anlamına gelir. O da bunu yapar ve ölüme, zamanın kesintiye uğramasına tepki göstererek yerleşik kanıyı tersine döndürür. Bu dizede "sıcak göğüs" bağdaştırması "tatlı mezar" bağdaştırması ile değiştirim ilişkisi içindedir: $\mathrm{Bu}$ nedenle sıcak göğsün anlamının tatlı mezara bağlı olduğu açıktır.

Şarap ve bereket tanrısı Dionysos'un babası Zeus'a "éternel Semeur", (ölümsüz Rençper) "sonsuz" ekici yayıcı, aktarıcı diye birbirini tanımlayan anlamlar yüklenmiştir, Dionysos, ben (sonsuz Ekici'nin serptiği_değerli tohumum) der ve bu anlamlandırıcı nitelemeler büyük olasılıkla aynı zamanda hem tanrı, hem insan olan Dionysos'un yeryüzündeki edimlerinin karşılığı olarak sözcelenmiştir. Şiirde büyük harfle yazılarak öne çıkarılan "éternel Semeur" (ölümsüz Rençper) bağdaştırması şiirin anlamını açan ve öznenin aslında ne demek istediğini gösteren değerli tohumun doğurgan niteliklerinin şiir dilindeki karşılı̆̆ıdır: (Grain précieux jeté par l'éternel Semeur / ölümsüz Rençper'in ektiği değerli tohumuyum ben) "Semeur" (ekici) ismi Dionysos'un bu değerli tohum oluş niteliğine vurgu yapmak üzere özellikle öne çıkarılmıştır. Değerli tohum bağdaştırması iki farklı göndermenin karşılığıdır; bunlardan ilki üzüm meyvesinin (değerli) tohumu, ikincisi ise (Semele) efsanesine bağll olarak öne çıarılan Zeus'un (oğlu) ve onun değerli tohumudur: Bilindiği gibi, Hellen'lerin baş tanrısı Zeus'tur, Dionysos gibi dışardan gelme bir tanrısal varlığı ne yapıp edip onun buyruğuna sokmak, ondan doğmuş olarak göstermek gerekmektedir, işte söylen şiirde böyle bir bağlantı kurma çabasının olağ̉an sonucu olarak ortaya çıkarılmıştır. Dionysos söyleninin şiir dilindeki karşılığı tanrının insana bağışladığı değişim gücüdür. Hamilton'a göre, Zeus, Semele'nin bütün dileklerini yerine getireceğine Styks ırmağ üzerine yemin etmiştir. Semele'nin dileği ise onu tanrı giysileri ve görüntüsü içinde tüm görkemiyle görmektir ve Zeus bu dileği yerine getirdiğinde Semele onun yakıcı ışıltısına dayanamayarak ölür. Böylece Dionysos ateşten doğmuş ve yağmur tarafından yetiştirilmiş ve gittiği yerlerde insana şarap yapmayı öğretmiştir (Hamilton, 2004: 35). Dionysos'un insana üzüm üretmeyi ve üzümden şarap yapmayı öğretmesi onun insan türü üzerinden geleceğe yaptığı yatırımın açık göstergesidir: Bu bağlamda yatırım bir güç'tür. Güç olarak da doğrudan tasarım içerisinde yer almaz. Diyapozitif projeksiyonu nasıl ışı demetini ekran üzerine yansıtmaz ise yatırım da tasarıma aynen yansımayıp oraya sadece izini bırakır. Bu iz etkileşim sisteminin biçimidir (DanonBoileau, 1998: 25). Dionysos insanlara dönüşüm yapma gücü verecek büyülü (nesne) şarabı bulmuştur: "Bir sanattır kalabalığın tadını çıkarmak; beşiğinde bir periden kılık değiştirme, maske zevkini, ev kinini, yolculuk tutkusunu almış kişi, yalnız o kişi, canlılıkta kana kana sarhoş olur, hem de insan türünün sırtından sağlar içkisini." (Baudelaire, Paris Sıkıntısı, 1984: 27) Ozan insan kalabalığının sağladığı canlılıkta Dionysos'un üzümleri olgunlaştıran yakıcı sıcaklığından ve asmalara can veren yaşam suyundan beslenir. Zaten kılık değiştirme, çılgınca davranma, gürültü çıkarma, tiz haykırışlar, kendinden geçme Dionysos'a özgü davranışlardır (Hamilton, 2004: 36/Fink, 2010: 124). Üstelik Dionysos'un insana üzüm yetiştirmeyi ve ondan şarap elde etmeyi öğretmesi bir süreklilik ve ilişkiyi yatırıma dönüsștürme bağıntısıyla insanın şarap üretimine devam edeceği gerçeği Baudelaire'deki "içkisini insan türünün sırtından sağlama" garantisini açıllar: Doğal olarak insanlar şarap üretimini sürdürdükleri sürece ozan da içkisini onların sırtından elde etmeyi sürdürecektir.

Şarabın Ruhu'nda yine karşılıklı olarak toplumun ozana ve ozanın topluma bakışını ve kitleye eleştirisini Dionysos söyleni yoluyla etkinleştirdiğine ilişkin başka ayrıntılar yer alıyor: Sözgelimi, toplum kendini gerçeklerden uzaklaştıracak ve uyuşturacak afyonlar arar, bu nedenle şiir aracılığılyla güncelleştirilen/etkinleştirilen bir söylende bu şekilde ezber bozan bir iletinin bulunmasını anlamaz, anlamak istemez; bu isteksizlik, Dionysos'un öğretisine karşı da gösterilmiştir. Buna bağlı olarak, Dionysos'un kişiliğinde bulunan öz nitelikler söz konusu edildiğinde toplumun ozana gösterdiği yok sayan ve haksız tepkinin bir benzerinin 
ona da gösterildiğine tanık oluyoruz. Dionysos insanların karşısına gerçek bir tanrı kimliğinde çıtı̆̆ zaman kimse onu dinlemez/anlamaz; üstelik onunla alay ederek onun insanlar üzerinde kurduğu saygınlığını yerle bir etmek için asılsız söylentiler üretirler. Onların bu inançsızlığı karşılığında elde ettikleri yalnızca yıkımdır ve bu yıkıma bağlı olarak içinde insanların bulunduğu geminin güvertesini simgesel şarap seli basar ve bu sirada büyünün gücüyle yelkenin üstünde olgun salkımlarıyla bir (asma) belirir ve gemideki bütün korsanlar can derdine düşerek son bir hamleyle denize atlarlar ve korsanların ayakları suya değer değmez ortaya çıkan sonuç bir metamorfozdur; hepsi birer yunus balığına dönüşürler. $\mathrm{Bu}$ nedenle Dionysos kendine inananlara bu birbirinden farklı iki değişik yüzünü gösterir: yerine göre sevinç de verir özgürlük de verir, fakat buna karşılık olarak yabanıl bir yıkım da verebilir. Baudelaire, Şarabın Ruhu'nda şarabın bu canlılık ve zevk veren yanını kullanır: (eşinin esrik gözlerini tutuştururum/ oğluna güç veririm renk katarım yüzüne) der. Burada şiirin öznesi, Dionysos'un insanlar üzerindeki yaptırım gücüne anıştırmada bulunarak, bu gücü "tutuşturmak/güç vermek/ renk katmak" gibi eylemlerle belirginleştiriyor. Yine bu hem insana, hem de üzüm asmasına gönderimde bulunan dizelerle yüzüne renk katmak deyişiyle görünüşte bir odundan farksız kuru asma dalının baharda yeniden dirilişine vurgu yapılmaktadır. Bu bağlamda bitkiyle insan türü arasında yakınlaştırma ilgisi kurularak (renksiz) yaşama renk katma deyişi "tutuştururum esrik gözlerini eşinin" dizesiyle, kendi söylemine kanıtlar oluşturarak, büyüyen oğul/tutuşturulan gözler üzüm asmasının güneşte kızarması, üzümün cinsine göre sararması ya da kararması, renk değiştirmesi, yani dönüşmesinde üzümle insan arasındaki benzerliklerden yararlanılmıştır. Şiirde eylemler arası eşzamanlılık imleyen "tutuşturum/güç veririm/ renk katarım" gibi sıralı eylemler için bir dönüştürme işlevi üstlenen ve ikinci / üçüncü dizeyi aynı yinelemeli yapıya bağlayan süreklilik göstergesi gözlerini tutuştururum, (oğluna) güç veririm, (yaşamına) renk katarım gibi genelleme ifadeleri bir durumdan diğerine geçişi gösterdiği gibi, söylenden beslenen nitelikleriyle dizeler arası uslamsal bağıntıyı da sağlamlaştırır.

\section{Gelecek Tasarimı}

Je ne serai point ingrat ni malfaisant (nankör, kötücül olmayacağım): Bu dizede benzeyenin yerine kullanılan ve dizenin tüm anlam yükünü taşıan tasarımsal bir Dionysos ana benzetileni gizli bir içerik olarak bulunuyor; bu içerik şiirde kendisine değişik ve çoklu nitelikler yüklenerek yeniden üretilmiştir ve Dionysos şïrde konuşan özne kimliğinde ete kemiğe bürünmüştür. Toplam yirmi dört dizeden oluşan şiirin ilk on beş dizesi, sekizinci dize dışında "8Mais je ne serai point ingrat ni malfaisant" şimdiki zaman kipinde sözceleniyor; bu dizelerde geleceğe yapılan yatırım düşüncesine bağlı olarak şiirin sözdizimsel boyutunda, sözce anı ile sözcelem anı arasında zamansal fark bulunmaktadır: Bu dizeler sözce zamanından daha sonra gerçekleşecek durumları belirtiyor. On altıncı dizeden başlayarak gelecek zaman kullanımı görülür; bu şekilde şiirin sözdizimsel boyutunda, sözce anı ile sözcelem anı birbirine eşitlenir:

16Tu me glorifieras et tu seras content ("sen" beni yücelteceksin ve bana hayran kalacaksin) yani, ben (Dionysos) olarak yaşamın boyunca senin için birçok iş yapacağıma, sana yatırım yapacağıma söz veriyorum, senin karşılık olarak beni ululaman ve bana hayranlık duyman mutlu olmana yetecek.

17J'allumerai les yeux de ta femme ravie ("ben" eşinin esrik gözlerini tutușturacağım)

18A ton fils je rendrai sa force et ses couleurs ("ben" oğluna güç vereceğim yüzüne renk katacă̆ım)

19Et serai pour ce frêle athlète de la vie ("ben" ömrün bu narin atleti için yağ olacağım) 
20L'huile qui raffermit les muscles des lutteurs. (Güreşçilerin kaslarını sağlamlaştıran)

21En toi je tomberai, végétale ambroisie, (düşeceğim içine, tanrısal balözü "ben")

22Grain précieux jeté par l'éternel Semeur, (Değerli tohum, sonsuz Ekici'nin serptiği)

23Pour que de notre amour naisse la poésie (Şiir doğsun diye ikimizin sevgisinden)

24Qui jaillira vers Dieu comme une rare fleur (sen ve ben "biz" yeni bir bedende benzersiz bir çiçek gövdesinde birlikte Tanrı'ya yükseleceğiz) gibi gelecek zaman belirleyicileri eylemin yönünün geleceğe dönük bir biçimde gelişeceğini ve Dionysos'un (uz)görür kimliğinde ve gözetiminde sağlanan bu esenli ortamın șimdi olduğu gibi gelecekte de korunarak sürdürüleceğini imliyor. Gelecek zaman kipi ileride olması, gerçekleşmesi beklenen eylemin belirttiği zaman kavramının, içinde bulunulan zamandan sonraya ait olduğunu gösteren kiptir:

Sözcelem öznesi şarap üzerinden insana yatırım yapan Dionysos'un sözleriyle ilerde (oradayarın- yakın/ uzak gelecekte) bir kazanç sağlama yolunda niyetini bildirerek neler yapacağını gelecek zaman kipinde sözceliyor.

(Entends-tu retentir les refrains des dimanches / kulak ver yankısına pazar şarkılarının) dizesindeki retentir eylemi çınlamak, yankılanmak ve gürlemek anlamlarına gelir: refrain sözcüğü şarkıların sürekli yinelenen bağlantı bölümünü belirtir, dolayısıyla pazar günü kiliselerde okunan ilahilerin yinelenen birimleri kast edilerek ayinlerde aktarılan Dionysos öğretilerinin, İsa'nın geniş halk kitlelerine ulaşması üzerindeki katkısına anıştırmada bulunur. Bilindiği gibi, şarap kırmızı renginden dolayı İsa'nın kanını ve canını simgeler, Davut peygamberden başlayarak süregelen ayinlerde katılımcılara bir iletinin gereği olarak tattırılan şaraplı ekmek ise Ísa'nın bedenini imgeler. Böylece, şiirin öznesi hem şu an'a ilişkin bir boyut, yani süre, alışkanlık, yineleme ve hem de geleceğe gönderimde bulunarak deneyim kazanan insanın şarap üzerinden elde edeceği gücün etkisini gösteriyor. (Les coudes sur la table et retroussant tes manches / dirseklerini daya, kalkık dursun kolların) dizesinde duadan söz edilmeden artgönderim yoluyla bir (dua) söyleminin karşıllğı gizlenmiştir: Dirsekler masada kollar kalkık veya kıvrılmış tanımlamasında ardındaki gerçeği buldurma yoluyla Dionysos yakarı ayinlerine gönderme yapılıyor.

A ton fils je rendrai sa force et ses couleurs (tutuștururum esrik gözlerini eșinin/oğluna güc veririm renk katarım yüzüne) et serai pour ce frêle athlète de la vie (yağ olurum ömrün bu narin atleti için) burada sözü edilen "narin atlet" bağdaştırması anne babanın gözünde çocuklarını imler, onlar uzun yaşam koşusunda çocuklarına güç verecek, yüzünün rengini soldurmayacak merhemler ararlar. Oğlunu orada, burada sabah akşam gezinir gösterirken onun renksiz yaşamına renk katmaktan söz eder. Bu merhemi onlara sağlayacak olan da Dionysos, yani şarabın gücüdür. Böylece, dizisel veya dizimsel biçim/içerik öne çıkarılmış, anlam parçalara ayrılmış, her bir parça kendi içinde (frêle athlète de la vie) uzun yaşam serüveninin körpe koşucusu gibi bağdaştırmalarla kendi anlam katmanını yaratmıştır. Yani, şiirde Dionysos'un esinlediği değerler dizisi, Dionysos'dan açıkça söz edilmeden, üzüm / oğul / güreşçi benzerliği üzerinden dile getirilmiştir.

"L'huile qui raffermit les muscles des lutteurs (güresçiler kasını sağlamlaștırsın diye) / en toi je tomberai, végétale ambroisie, (cennet taamı olup düşeceğim gövdene)" dizelerinde Dionysos'un çocukları ve insanları besleyip büyüten, insanları dinginliğe eriştiren tanrısal (çiçek özü) gibi niteliklerine vurgu yapıllyor. Şarap söylemini kuran tin devinimi içinde yer alan sözcelem öznesinin "ateş", "alev" ve "ısı" insana ve bitkiye can veren sıcaklık bildirimleriyle didinme, ter ve kavurucu güneş kaynaklı belirlemeleri tanrısal (balözü) gibi 
üzümün yetişmesinde gerekli olan etkenleri açımlıyor ve çiçeğin üzüme dönüşüm aşamalarını belirleme gereği gerçek anlam belirleyicilerini yeni bir boyuta taşıyarak yan anlam belirleyicilerine dönüştürüyor ve (pembe balmumu ve cam zindan) gibi özünde ışığa ve renge değgin yeni adlandırmalara yol açıyor. Dionysos insanları birbirinden ayırmadan zengine de, yoksula da şarabın tine katkı sağlayan esenliğini aktarır ve onlara en sıradan insanın yaşadığı gibi büyüklenmeden yaşamayı ögütler. Yaşamın tadını çıkarmayan, günlerin gecelerin zevkine varamayan insanları (kulak ver yankısına pazar şarkılarının/ ve umuda, coşkulu kalbimde cıvıldayan/ dirseklerini daya, kalkık dursun kolların / yücelteceksin beni ve kalacaksın hayran) diyerek, Dionysos şölenlerinin sevincini yaşamaya çağırır.

\section{Sonuç}

(Bunun için askımızdan șiir doğsun yine / benzersiz bir çiçek gibi Tanrı'ya yükselen!) dizelerinde şiirin dili Tanrıyla insan arasında bağlantıyı sağlayan benzersiz (az bulunur) eşsiz bir çiçekle, sarmaşık gibi gökyüzüne yükselen üzüm asmasının çiçeğiyle bağdaştırılıyor. Bilindiği gibi, üzüm çiçekleri sarı, mor ve yeşil renklerde salkım salkım açarlar ve küçük oluşları nedeniyle fazla dikkat çekmezler. Bu bağdaştırmadaki (eşsiz bir çiçek) nitelemesi düzdeğişmece yoluyla üzüm üzerinden şaraba yapılan bir gönderimdir: Üzüm asması, meyve veren diğer bitkilerden farklıdır çünkü hepsinden çok budanır ve fazla suya gereksinim duymaz. Kış mevsiminde yapraksız, çıplak ve eğri büğrüdür, onu kışın görenler canlı olmadığına, öldüğüne inanırlar, fakat bahar geldiğinde kışınki kuru görüntüsüne inat yeniden canlanır ve dirilir. Yıl boyunca bir süreklilik ilkesiyle yaşam döngüsünü sağlamak üzere yeniden ölür, sonra yeniden dirilir. Bu şïrde göstergelerin farklı kullanımlarından beslenen söylen tanrısı, insan gibi davranıyor, düşünüyor ve konuşuyorken gösterilir. Ozan sözcükleri, yadırgatıcı sözdizimi düzenlemeleri ve bağdaştırmalar içinde kullanarak onlara yeni anlamlar yüklemiş ve bu yolla şarap söylenini çağrışım gücü yüksek yeni bir algılama boyuta taşımayı başarmıştır. Ozanın şiirde yatırımı önceleyen bir tasarım dizgesi kullanması üzümün şaraba dönüşüm (ön) koşuluna bağlanmış ve son çözümlemede Dionysos söyleni Baudelaire şiirinin bilişsel söylemini oluşturmuştur.

\section{Kaynakça}

Baudelaire, C. (2011). Les Fleurs du Mal. Paris: réimpression Éfélé de l'édition PouletMalassis et de Broise, 1861, BeQ, Kötülük Çiçekleri, Ahmet Necdet Çevirisi,2006, İstanbul: Dharma.

Baudelaire, C. (2009). Le Spleen de Paris, Les Paradis artificiels. Bookking International, Les Fleurs du mal suivies du Spleen de Paris: Éditions de Clairefontaine, 1947, La Guilde du Livre, Lausanne. Introduction, éclaircissements et notes de Blaise Allan, BeQ, Jean-Yves Dupuis, Paris/ Paris Sıkıntısı (Tahsin YücelÇevirisi), 1984, İstanbul: Adam.

Caron, J. (1983). Les Régulations du Discours, psycholinguistique et pragmatique du langage. Paris: PUF.

Chevalier, J. \& Gheerbrant, A. (1982). Dictionnaire des symboles. Paris: Editions Robert Laffont S.A et Editions Jupiter.

Chomsky, N. (2001). Language and Mind. Third Edition, Cambridge University Press, (Dil ve Zihin, Ahmet Kocaman çevirisi) Ankara: Ayraç.

Danon-Boileau, L. (2007). Le sujet de l'énonciation, Psychanalyse et linguistique, Réference et Enonciation, L'homme dans la Langue. Gap, Ophrys. Sözcelem Öznesi-Psikanaliz ve 
Dilbilim, Mehmet Baştürk çevirisi, Erzurưm: Atatürk Üniversitesi Yayınları, 1998/ 2.Basım: Psikanaliz ve Dilbilim (Sözceleme Öznesi) Nisan. Ankara: De Ki Basım Yayım.

David-Ménard, M. (2005). Deleuze et la psychanalyse, l'altercation. Paris: PUF.

Doğan, M. N. (2008). Divan Şiirinde "Şarap" metaforları. İstanbul: Türk Dili ve Edebiyat Dergisi, Sayı:38.

Erhat, A. (1996). Mitoloji Sözlüğü. İstanbul: Remzi.

Fink, G. (2010). Antik Mitolojide Kim Kimdir. Serpil Erfındık Yalçın (çev.) İzmir: İlya İzmir.

Fontanier, P. (1977). Les Figures du discours, Introduction par Gérard Genette. Paris: Flammarion.

Greimas, A, J. et Courtes, J. (1979). Sémiotique: Dictionnaire raisonné de la théorie du langage. Paris: Classiques Hachette.

Greimas, A. (1972). Essais de sémiotique poétique. Paris: Larousse.

Hamilton, E. (2004). Mitologya. Ülkü Tamer (Çev.) İstanbul: Varlık.

İndirkaş, Z. (2012). Tanrının Maskesi ya da Maskenin Tanrısı. İstanbul: Tizatro Dergisi, 335, sayl 5 .

Kristeva, J. (1974). La Révolution du langage poétique. Paris: Editions du Seuil.

Le Nouveau Petit Robert (1993). Dictionnaire alphabétique et analogique de la langue française. Montréal, Canada.

Saraç, T. (1989). Fransızca-Türkçe Büyük Sözlük. İstanbul: Adam.

Todorov, T. (1979). Sémantique de la poésie. Paris: Editions du Seuil.

Türk Dil Kurumu. (1983). Türkçe Sözlük. Ankara: TDK.

Vardar, B., Güz N., Öztokat E., Senemoğlu O., Sözer E. (1988). Açılamalı Dilbilim Terimleri Sözlüğü. İstanbul: ABC.

Yalt, A. R. (1975). Fransızca-Türkçe Deyimler Sözlüğü, İstanbul: Remzi. 
Mainadlar ve ahşap sütun üzerinde giyimli ve maskeli Dionysos imgesi

(Frickenhaus, Lenaenwasen, PI. 29A; P.E. Arias, A. History of 1000 Years of Greek

Vase Painting, pp. 372-375, PI. 206)

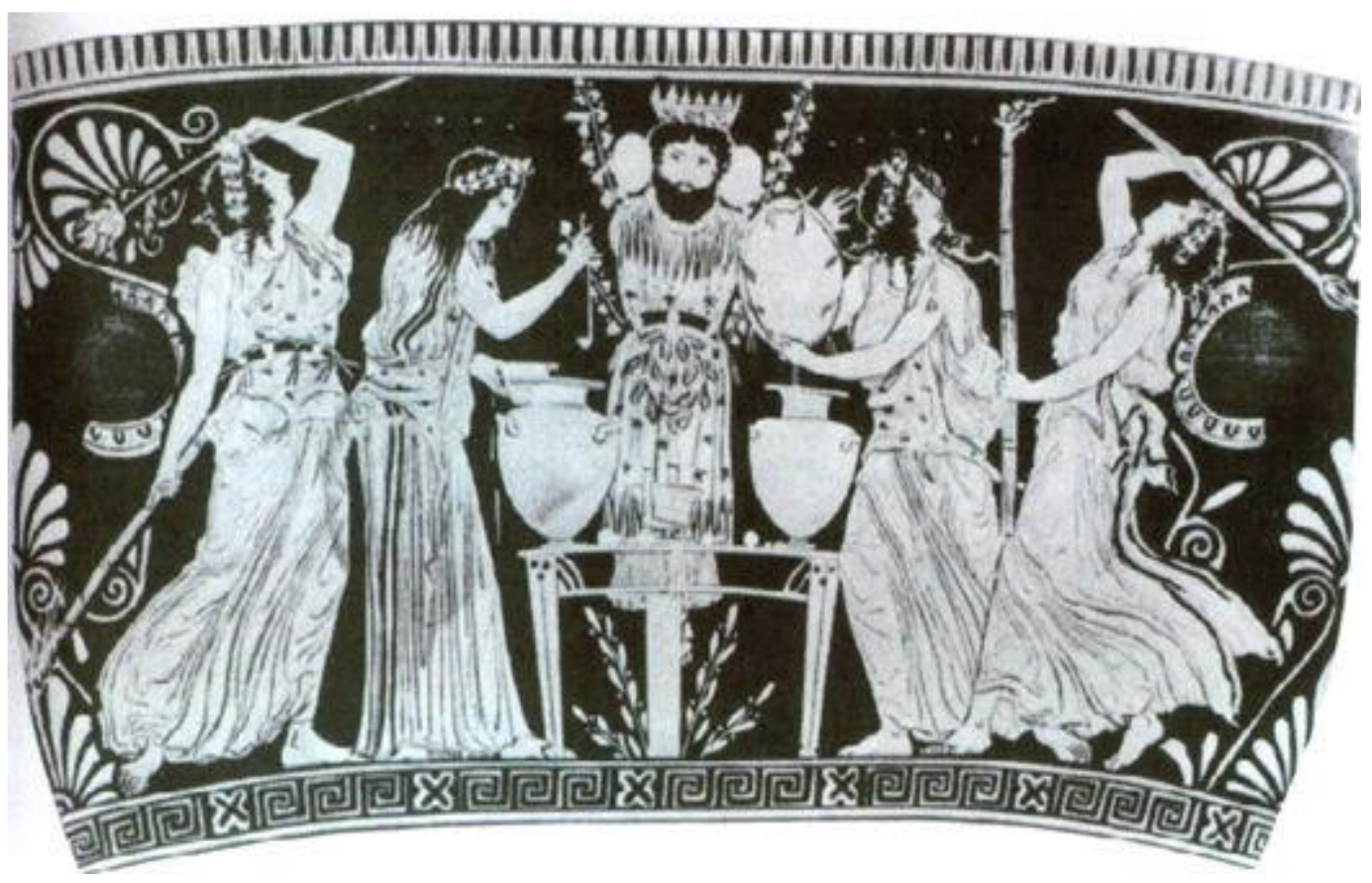

